\title{
Hubungan Regulasi diri dengan Prokrastinasi Akademik Mahasiswa Magister yang bekerja pada Perguruan Tinggi Surabaya
}

\author{
Nurul Fajriani ${ }^{11 *}$, Nerinda Rizky $\mathrm{F}^{2}$, Ismawati ${ }^{3}$, Fathan Abidi A. ${ }^{4}$ \\ 1,2,3,4 Universitas Airlangga Surabaya, Indonesia \\ * Corresponding Author. E-mail: ${ }^{1}$ nurul.fajriani-2018@psikologi.unair.ac.id
}

Receive: 13/05/2021

Accepted: $23 / 08 / 2021$

Published: 01/10/2021

\begin{abstract}
Abstrak
Penelitian meta-analisis oleh Steel (2007) di Universitas Calgary bahwa 80\% hingga 95\% mahasiswa melakukan prokrastinasi, terutama saat melakukan tugas kuliah. Pada penelitian Klassen, Krawchuk dan Rajani (2008) di universitas Kanada juga menghasilkan data bahwa prokrastinasi pada siswa terkait dengan tingkat regulasi diri yang lebih rendah.Dalam penelitian ini, ditemukan bahwa siswa dengan kemampuan untuk mengatur diri yang rendah memiliki IPK yang lebih rendah,dan lebih banyak menunda..Tujuan penelitian ini untuk mengetahui mengenai hubungan prokrastinasi akademik dengan regulasi diri mahasiswa. metode penelitian kuantitatif.Penelitian ini merupakan penelitian kuantitatif dengan menggunakan metode survey. Hasil yang didapatkan menunjukkan nilai signifikansi $0,000 \quad(p<0,05)$.Hasil tersebut menunjukkan adanya korelasi negatif antara prokrastinasi akademik dengan regulasi diri dan menunjukkan hubungan yang signifikan.Sehingga ada hubungan yang signifikan prokrastinasi akademik dengan regulasi diri mahasiswa magister yang bekerja.
\end{abstract}

Kata Kunci: Prokrastinasi, regulasi diri, dan mahasiswa

\section{Abstract}

A meta-analysis research by Steel (2007) at the University of Calgary found that $80 \%$ to $95 \%$ of students procrastinate, especially while doing course work. In Klassen's research, Krawchuk and Rajani (2008) at a Canadian university also produced data that procrastination in students was associated with lower levels of self-regulation.In this study, it was found that students with low self-regulating ability had lower Grade Point Average, and were more procrastinated.The purposed of this study was to determine the relationship between academic procrastination and student self-regulation. quantitative research methods. This research was a quantitative study using a survey method. The results obtained showed a significance value of $0.000(p<0.05)$. These results indicate a negative correlation between academic procrastination and selfregulation and show a significant relationship. So that there was a significant relationship between academic procrastination and self-regulation of working master students.

Keywords: Procrastination, self-regulation, and students 


\section{Pendahuluan}

Perguruan tinggi adalah suatu lembaga bagi individu yang berstatus sebagai mahasiswa dalam menambah ilmu pengetahuan berdasarkan jurusan yang dipilihnya. Selain itu, jenjang dalam perguruan tinggi yaitu D1, D2, D3, S1, S2, dan S3. Tugas dan tanggung jawab pada setiap jenjang pendidikan tersebut semakin tinggi semakin kompleks. Oleh karena itu, dalam mengerjakan tugas sebagai mahasiswa merupakan suatu kewajiban untuk diselesaikan. Namun, faktanya masih banyak ditemukan mahasiswa yang secara sengaja menunda-nunda waktu dalam menyelesaikan tugasnya tersebut. Topik prokrastinasi memang bukan fenomena yang baru, namun, di zaman modern ini ketika banyak orang dihadapkan dengan banyak tugas yang harus diselesaikan dalam aturan dan waktu yang singkat, tidak mengherankan jika prokrastinasi selalu menjadi topik yang penting. Bentuk umum penundaan adalah bagi siswa untuk menunda memulai mengerjakan suatu tugas melewati batas waktu yang dijadwalkan dan kemudian harus bekerja lebih giat untuk menyelesaikannya tepat waktu (Neville, 2007).

Prokrastinasi masih banyak dilakukan mahasiswa hingga saat ini. Sebuah penelitian metaanalisis oleh Steel (2007) di Universitas Calgary melaporkan bahwa 80\% hingga 95\% mahasiswa melakukan prokrastinasi, terutama saat melakukan tugas kuliah. Survei yang dilakukan oleh Ross (2014) yang mensurvei sekitar 1.300 pelajar sekolah menengah atas dan perguruan tinggi menunjukkan sebanyak 69\% mahasiswa melakukan prokrastinasi saat mengerjakan makalah. Bahkan, lebih dari separuh mahasiswa atau 51\% menyatakan bahwa mereka kemungkinan besar akan menyelesaikan sebuah makalah di malam sebelum waktunya, dan 7 persen mengatakan mereka cenderung membutuhkan tambahan waktu.. Hampir 8 dari 10 mahasiswa atau 79\% mengatakan bahwa mereka telah melakukan setidaknya satu sistem kerja satu malam untuk menyelesaikan tugas di setiap semester. Berdasarkan hasil penelitian sebelumnya dapat dikatakan bahwa perilaku prokrastinasi tersebut akan memunculkan dampak yang negatif bagi individu yang melakukannya. Hasil penelitian Ross (2014) menunjukkan sebanyak 87\% partisipan melakukan prokrastinasi dan itu mempengaruhi kinerjanya, dengan hasil 45\% prokrastinasi berdampak negatif terhadap nilai.
Dalam survei di University of Denver School of Education oleh Green (1997) menemukan bahwa prokrastinasi adalah salah satu alasan utama mahasiswa doktoral gagal menyelesaikan disertasi mereka. Mastuti (2009) dampak yang dimunculkan ketika perilaku prokrastinasi terjadi pada individu yaitu terjadinya penurunan produktivitas dan semangat kerja yang juga akan berdampak pada rendahnya kualitas hidup individu.

Terdapat banyak hal yang berkaitan dengan prokrastinasi. Penelitian oleh Ford (2014) di Universitas Southern Adventist menemukan bahwa sebanyak $31,25 \quad \%$ mahasiswa adalah prokrastinator pasif karena keraguan dalam bertindak dan gagforal menyelesaikan tugas tepat waktu, dan sebanyak 68,75\% adalah prokrastinator aktif atau lebih suka bekerja di bawah tekanan dan membuat keputusan yang sengaja untuk menunda. Ferrari, Johnson dan Cown (1995) menyebutkan hal-hal yang berkaitan dengan tingkat prokrastinasi adalah faktor eksternal dari luar individu, seperti model pengasuhan orang tua, kondisi lingkungan dan dukungan sosial. Penelitian lain oleh Park dan Sperling (2012) menunjukkan bahwa prokrastinasi akademik berhubungan dengan pengaturan diri yang buruk. Penelitian ini juga sependapat dengan Jiao dkk (2011) yang menunjukkan bahwa mahasiswa pascasarjana memiliki kecenderungan untuk prokrastinasi dan memiliki kendala dalam mengatur dirinya. Penelitian yang telah dilakukan oleh Klassen, Krawchuk dan Rajani (2008) di universitas Kanada juga menghasilkan data bahwa prokrastinasi pada siswa terkait dengan tingkat regulasi diri yang lebih rendah. Dalam penelitian ini, ditemukan bahwa siswa dengan kemampuan untuk mengatur diri yang rendah memiliki IPK yang lebih rendah, dan lebih banyak menunda.

Berdasarkan pandangan beberapa peneliti tersebut, terdapat berbagai pendapat pada hal-hal yang berhubungan dengan prokrastinasi akademik mahasiswa. Adanya perbedaan dan kesenjangan ini menjadi celah bagi peneliti untuk melakukan penelitian mengenai hubungan antara prokrastinasi akademik dengan regulasi diri mahasiswa. Tujuan penelitian ini adalah untuk mengetahui hubungan regulasi diri terhadap prokrastinasi akademik pada mahasiswa yang kuliah sambil bekerja. Penelitian ini juga bertujuan untuk mengetahui solusi untuk mengatasi mahasiswa yang melakukan prokrastinasi agar membantu dirinya sendiri dan juga universitas 
dalam mengelola sumber daya manusianya. Solomon dan Rothblum (1984) menyatakan bahwa prokrastinasi adalah kecenderungan untuk menunda dalam mengawali maupun mengakhiri kinerja secara keseluruhan untuk melakukan aktivitas lain yang tidak bermanfaat sehingga kinerja menjadi terhambat, tugas tidak dapat terselesaikan tepat waktu. Milgram (1991) menjelaskan empat komponen penting dari prokrastinasi. Pertama, yaitu serangkaian perilaku penundaan. Penundaan dapat dikategorikan prokrastinasi apabila penundaan tersebut dilakukan secara berulang-ulang. Kedua, menghasilkan perilaku di bawah standar. Prokrastinasi memperkuat individu agar tidak melakukan proses-proses penyelesaian tugas tepat pada waktunya, sehingga hasil yang diperoleh tidak dapat memenuhi standar dan tidak memuaskan. Ketiga, melibatkan suatu tugas yang dipersepsikan. Individu akan melakukan tugas yang lebih disukai dan tidak menjadi prioritas daripada melakukan kewajibannya. Keempat, menghasilkan keadaan emosional yang tidak menyenangkan. Individu yang melakukan prokrastinasi akan merasakan kegelisahan dan kecemasan karena kewajiban yang belum terselesaikan.

Regulasi diri merujuk pada dilakukannya kontrol terhadap diri sendiri, terutama untuk menjaga diri tetap berada dalam jalur yang sesuai dengan standar yang dikehendaki (Vohs \& Baumiester, 2004). Terdapat tujuh dimensi yang mampu menjadikan regulasi diri pada individu berjalan secara efektif menurut Miller dan Brown (1991), yaitu (a) Receiving, atau menerima informasi yang relevan, (b) Evaluating, atau mengevaluasi informasi dan membandingkan ke norma, (c) Trigerring. Atau memicu perubahan (d) Searching, atau mencari opsi pilihan, (e) Formulating, atau merumuskan rencana, (f) Implementing, atau menerapkan rencana dan (g) Assessing, atau menilai keefektifan rencana. Hubungan antara regulasi diri dengan prokrastinasi akademik menurut Muslimah (2016) menunjukkan bahwa semakin tinggi regulasi diri yang dimiliki mahasiswa, maka perilaku prokrastinasi akan semakin rendah, begitu pula sebaliknya, apabila regulasi diri mahasiswa tersebut rendah maka perilaku prokrastinasinya semakin tinggi. Bakis \& Duru (2015) menyatakan bahwa seseorang yang memiliki kemampuan regulasi diri yang rendah maka akan gagal dalam mengatur emosi, pikiran, perilaku dan waktu mereka dengan seefektif mungkin dan tidak memiliki kekuatan serta kemampuan untuk berhasil. Beberapa peneliti sependapat bahwa prokrastinasi memiliki hubungan erat dengan regulasi diri (Baumeister et al. 2007; Howell \& Watson 2007). Pychyl dan Flett (2012) menyatakan bahwa perilaku prokrastinasi merupakan bentuk perilaku yang mencerminkan bahwa adanya kegagalan individu dalam mengatur dirinya atau kurangnya kemampuan regulasi dirinya.

Sarajar (2016) menambahkan berdasarkan hasil eksperimen yang dilakukan menunjukkan bahwa perilaku prokrastinasi penyelesaian skripsi mahasiswa tingkat akhir yang mendapat pelatihan Self-Regulated Learning mengalami penurunan dibandingkan subjek yang tidak mendapat pelatihan Self-Regulated Learning. Sehingga berdasarkan eksperimen tersebut dapat dikatakan bahwa apabila regulasi diri individu tinggi maka perilaku proktastinasinya rendah, begitupun sebaliknya. Muhson (2017) menghasilkan penelitian yang menunjukkan bahwa mahasiswa yang menjalani part-time job berefek pada signifikansi aktivitasnya dalam bekerja dan memeroleh prestasi di akademik. Mahasiswa yang menjalani part-time job seolah mempunyai waktu dalam menyelesaikan tanggung jawab akademik lebih sedikit jika dibandingkan dengan mahasiswa yang tidak memiliki pekerjaan. Serta mahasiswa yang bekerja tersebut cenderung memiliki prestasi akademik yang lebih rendah daripada mahasiswa yang tidak bekerja.

Aziz (2015) menjelaskan bahwa mahasiswa pascasarjana (S2) yaitu mahasiswa yang memiliki beban tanggung jawab yang tidak sama dengan mahasiswa tingkat Strata Satu. Perbedaannya dalam proses memperoleh pengetahuan, mahasiswa magister lebih dituntut untuk mendapatkan pengetahuan tersebut berdasarkan usahanya sendiri, tanpa dijelaskan langsung oleh tenaga pengajar yang ada. Disisi lain, tugas akademik yang diberikan lebih berat dibandingkan strata satu dan dituntut untuk menyelesaikannya dengan lebih efektif. Fenomena yang ditunjukkan pada mahasiswa pascasarjana di UIN Malang menunjukkan bahwa berdasarkan data akademik yang diperoleh terdapat mahasiswa yang belum lulus dan sudah berada pada semester sembilan. Berdasarkan hasil penelitian yang telah dilakukan, menunjukkan bahwa tingkat prokrastinasi akademik yang dialami oleh mahasiswa pascasarjana berada pada tingkat yang tinggi. Sebesar 70\% mahasiswa yang berada pada tingkat prokrastinasi tinggi.Berdasarkan dari beberapa hasil penelitian diatas, peneliti ingin menguji 
masalah ini lebih lanjut dengan melakukan penelitian survei mengenai hubungan regulasi diri terhadap prokrastinasi pada mahasiswa namun, lebih khusus pada mahasiswa yang memiliki kegiatan lain selain kuliah, yaitu mahasiswa magister yang bekerja, sehingga hipotesis dalam penelitian ini adalah terdapat hubungan antara regulasi diri dan prokrastinasi akademik.

\section{Metode Penelitian}

Desain penelitian yang digunakan dalam penelitian ini adalah metode penelitian kuantitatif. Penelitian ini merupakan penelitian kuantitatif dengan menggunakan metode survei. Survei adalah sebuah cara penelitian kuantitatif dengan jumlah subjek yang relatif besar yang diwawancarai atau masing-masing diberikan satu set standar pertanyaan yang disajikan dengan cara yang sama setiap kalinya (The Association for Quantative Research, 2016). Penelitian ini merupakan penelitian korelasional yang bertujuan untuk menguji keterkaitan antar variabel bedasarkan koefisien korelasi (Azwar, 2009).

Variabel pertama adalah prokastinasi, dimana prokastinasi pada penelitian kami menitik beratkan pada prokastinasi akademik pada mahasiswa magister yang memiliki peran ganda yakni sebagai mahasiswa sekaligus sebagai pekerja. Variabel kedua adalah variabel regulasi diri dimana regulasi diri pada penelitian kami menitik beratkan pada regulasi diri mahasiswa magister dalam menangani prokastinasi akademik.

Adapun kriteria partisipan pada penelitian ini memiliki karakteristik, yaitu:

1. Laki-laki atau Perempuan

2. Mahasiswa yang berusia antara 20-40 Tahun

3. Mahasiswa Magister di Perguruan Tinggi Surabaya

4. Memiliki pekerjaan yang menetap di salah satu instansi atau lembaga atau Sederajat

Adapun kriteria partisipan pada penelitian ini berjumlah sebanyak 30 mahasiswa. Adapun jumlah partisipan laki laki sebanyak 13 orang dan perempuan sebanyak 17 orang. Terdapat 27 partisipan yang pendidikan terakhirnya S1, dan 3 partisipan yang pendidikan terakhirnya S2. Usia rata-rata partisipan 26-35 tahun sebanyak 18 mahasiswa, 15-25 tahun sebanyak 11 mahasiswa, 1 mahasiswa berusia 40 tahun. Adapun identitas pekerjaan dari partisipan 33\% berprofesi sebagai guru yaitu 10 orang, $13 \%$ berprofesi sebagai pegawai swasta, $13 \%$ berprofesi sebagai staff, sisanya masing-masing berprofesi yang berbedabeda. Teknik pengambilan sampel penelitian menggunakan purposive sampling, yaitu teknik penentuan sampel berdasarkan ciri dan sifat yang telah ditentukan sesuai dengan sebagai sumber data dapat digunakan sebagai sampel (Sugiyono, 2006).

Pada proses penyebaran kuisioner pada partisipan di penelitian ini peneliti tidak memberikan informed consent disebabkan karena keterbatasan waktu yang dimiliki oleh partisipan, sehingga kuisioner diberikan online, melalui google forms. Data dalam penelitian ini dikumpulkan menggunakan skala psikologi. Skala yang digunakan untuk mengukur prokrastinasi akademik adalah skala prokrastinasi yang diadaptasi dari penelitian sebelumnya yaitu (Abidi, 2017). Skala prokrastinasi akademik ini terdiri dari 28 aitem yang setiap aitemnya mewakili komponen prokrastinasi akademik oleh Milgram (1991). Skala ini menggunakan lima alternatif jawaban pada setiap pernyataannya, yaitu sangat tidak setuju (STS), tidak setuju (TS), netral (N), setuju (S) dan sangat setuju (SS).

Skala regulasi diri yang digunakan dalam penelitin ini skala yang diambil dari penelitian sebelumnya yaitu (Putri, 2016) yang menggunakan SRQ (Self Regulation Questionnaire). Penyusunan alat ukur tersebut dilakukan oleh Miller \& Brown (1991) dan selanjutnya diperbarui oleh Neal \& Carey (2005). Formulasi dari skala regulasi diri sebanyak 7 tahapan, antara lain receiving, evaluating, triggering, searching, formulating, implementing, assesing. Skala regulasi diri ini terdiri dari 38 aitem yang setiap aitemnya mewakili dimensi regulasi diri. Skala ini menggunakan lima alternatif jawaban pada setiap pernyataannya, yaitu sangat tidak setuju (STS), tidak setuju (TS), netral (N), setuju (S) dan sangat setuju (SS).

Uji validitas dilakukan untuk mengetahui ketepatan dan kecermatan skala dalam mengukur sesuai fungsinya. Suatu skala mempunyai validitas yang tinggi bila skala tersebut mengukur dengan tepat dan akurat sesuai dengan tujuan dan fungsi skala tersebut, begitu pula sebaliknya, validitas skala dikatakan rendah bila hasil pengukuran tidak relevan dengan tujuan dan fungsi skala (Azwar, 1996). Uji validitas dilakukan untuk mengetahui kesesuaian antara aitem-aitem dalam skala pengukuran dengan variabel operasional. Validitas yang akan digunakan dalam penelitian ini yaitu CVR (content validity ratio) dengan persyaratan nilai CVR $>0,5$. Uji reliabilitas dilakukan untuk 
mengukur konsistensi skala dalam mengukur variabel. Skala memiliki reliabilitas yang tinggi apabila menghasilkan data yang reliabel dan dapat dipercaya, yaitu diperoleh hasil pengukuran yang relatif sama pada beberapa kali pengukuran pada kelompok subjek yang sama (Azwar, 1996). Adapun hasil reliabilitas yang didapatkan yaitu:

Tabel 1. Tabel Reliabilitas

\begin{tabular}{lccc}
\hline No & Variabel & Koefisien Alpha Cronbach & Status \\
\hline 1. & $\begin{array}{c}\text { Prokrastinasi } \\
\text { Akademik }\end{array}$ & 0,785 & Reliabel \\
2. & Regulasi Diri & 0,899 & Reliabel \\
\hline
\end{tabular}

Reliabilitas skala dalam penelitian ini diukur melalui koefisien alpha cronbach yang diperoleh dari setiap skala variabel. Aitem-aitem skala variabel pengukuran dapat dikatakan reliabel jika memenuhi nilai signifikansi alpha cronbach > 0,7. Pada hasil uji reliabilitas, dapat diketahui bahwa kedua skala menunjukkan hasil yang reliabel. Nilai koefisien alpha cronbach pada skala prokrastinasi adalah 0,785 dan nilai koefisien alpha cronbach pada skala regulasi diri adalah 0,899 .

Adapun uji asumsi yang dilakukan adalah, uji normalitas, dan uji linieritas. Pengujian ini digunakan untuk mengetahui normalitas distribusi penyebaran data. Uji normalitas dilakukan menggunakan tes kolmogorov smirnov dan sebaran data dapat dikatakan bersifat normal jika nilai signifikansi kolmogorov smirnov mencapai > 0,05 .

Tabel 2. Tabel Normalitas

\begin{tabular}{cccc}
\hline & Tabel 2. Tabel Normalitas & \\
\hline No & Variabel & $\begin{array}{c}\text { Nilai Kolmogorov- } \\
\text { Smirnov }\end{array}$ & Status \\
\hline 1. & $\begin{array}{c}\text { Prokrastinasi } \\
\text { Akademik } \\
\text { Regulasi Diri }\end{array}$ & 0,200 & Normal \\
\hline & & 0,105 & Normal \\
\hline
\end{tabular}
hasil uji normalitas, dapat dengan uji korelasi product moment. Bertan (2016) uji diketahui bahwa sebaran data kedua variabal adalah normal, dengan nilai koefisiensi apah ada hubungan antara kedua variabel yang diteliti. Kolmogorov-Smirnov skala prokrastinasi akademik sebesar 0,200 dan nilai koefisiensi KolmogorovSmirnov skala regulasi diri sebesar 0,105 ( $p>0,05)$. Uji linieritas dilakukan untuk mengetahui hubungan keseimbangan antara pasangan data variabel bebas dan variabel terikat. Pasangan data dapat dikatakan linier jika memiliki bentuk gariłasil melintang dan mencapai nilai signifikansi linieritas $>0,05$. Berdasarkan hasil uji linieritas, dapat diketahui bahwa variabel prokrastinasi akademik menunjukkan hubungan yang linier dengan variabel regulasi diri, yaitu dengan nilai $p=0,682$ $(p>0,05)$. Berdasarkan uji asumsi yang telah dilakukan, maka dari itu memenuhi syarat dalam melakukan analisis data parametrik. Analisis data menggunakan aplikasi SPSS versi 20.0 for windows. Dan teknik analisis data yang digunakan adalah parametrik yaitu Pearson. Teknik analisis ini digunakan untuk mengetahui hubungan dari kedua variabel yang diteliti yaitu hubungan antara variabel prokrastinasi akademik dengan regulasi diri pada partisipan penelitian.

\section{Hasil Penelitian dan Pembahasan}

Berdasarkan distribusi frekuensi regulasi diri, dapat diketahui bahwa subjek yang paling banyak adalah mahasiswa yang memiliki tingkat regulasi diri yang tinggi, yaitu sebanyak 23 mahasiswa atau $76,7 \%$, sedangkan yang paling sedikit adalah mahasiswa yang memiliki tingkat regulasi diri yang sedang, sebanyak tiga mahasiwa atau 13,3\% dan tidak ada mahasiswa yang memiliki tingkat regulasi diri yang rendah dan sangat rendah. Berdasarkan distribusi frekuensi prokrastinasi akademik, dapat diketahui bahwa subjek yang paling banyak adalah mahasiswa yang memiliki tingkat prokrastinasi akademik yang rendah, yaitu sebanyak 21 mahasiswa atau $70 \%$ dan hanya satu mahasiswa yang memiliki tingkat prokrastinasi akademik yang tinggi, sedangkan tidak ada mahasiswa yang memiliki tingkat prokrastinasi akademik yang sangat tinggi dan sangat rendah.

Adapun uji hipotesis yang diajukan dalam penelitian ini adalah untuk mencari tahu apakah ada korelasi antara variabel regulasi diri dengan variabel prokrastinasi akademik pada Mahasiswa Magister yang sambil bekerja. Uji hipotesis menggunakan uji korelasi product moment uji ini digunakan karena data dalam penelitian ini memiliki jenis interval sehingga sesuai Tabel 3. Tabel Uji Hipotesis

\begin{tabular}{cccc} 
Variabel & $\mathrm{R}$ & $\mathrm{p}$ & Status \\
& & & \\
\hline $\begin{array}{c}\text { Hubungan Prokrastinasi dan Regulasi } \\
\text { diri }\end{array}$ & $-0,611$ & 0,000 & $\begin{array}{c}\text { Signifika } \\
\mathrm{n}\end{array}$
\end{tabular}

sil analisis hubungan antara prokrastinasi akademik dengan regulasi diri menunjukkan korelasi sebesar $\mathrm{R}=-0,611$. Hasil tersebut menunjukkan bahwa arah hubungan antara kedua variabel yaitu 
berhubungan negatif. Maka tingkat kekuatan korelasi antara variabel independen yaitu prokrastinasi akademik dengan variabel dependen yaitu regulasi diri menghasilkan korelasi negatif. Dapat diartikan bahwa semakin tinggi satu variabel, maka variabel lainnya akan semakin rendah, karena korelasinya yang negatif. Jadi, semakin tinggi tingkat prokrastinasi akademik mahasiswa, maka akan semakin rendah regulasi dirinya, dan begitu pula sebaliknya, semakin tinggi tingkat regulasi diri mahasiswa akan semakin rendah tingkat prokrastinasi akademiknya. Nilai $\mathrm{R}=$ $-0,611$ juga menunjukkan bahwa sebesar 0.00611 prokrastinasi akademik mahasiswa dipengaruhi oleh kemampuan regulasi dirinya, sisanya dipengaruhi oleh faktor lain.

Berdasarkan hasil tersebut menunjukkan nilai signifikansi atau Sig. (2-tailed) sebesar sebesar $0,000(\mathrm{p}<0,05)$. Hasil uji hipotesis ini menunjukkan adanya korelasi negatif antara prokrastinasi akademik dengan regulasi diri dan menunjukkan hubungan yang signifikan. Sehingga menunjukkan bahwa ada hubungan yang signifikan antara variabel prokrastinasi akademik dengan regulasi diri pada mahasiswa magister yang bekerja. Penelitian ini bertujuan untuk mengetahui apakah ada hubungan antara prokrastinasi akademik dengan regulasi diri yang dialami oleh mahasiswa Magister yang bekerja pada Perguruan Tinggi di Surabaya. Berdasarkan hasil analisis yang telah dilakukan oleh peneliti dapat disimpulkan bahwa Ho di tolak dan Ha di terima yang menunjukkan adanya hubungan antara prokrastinasi akademik dengan regulasi diri pada mahasiswa Magister yang bekerja pada Perguruan Tinggi di Surabaya.

Tabulasi silang berguna untuk menampilkan distribusi silang antar variabel. Hasil tabulasi silang dapat digunakan untuk melihat kecenderungan karakteristik sampel dalam bentuk data kategori. Berikut adalah tabel hasil tabulasi silang variabel prokrastinasi akademik dengan regulasi diri. Berdasarkan tabulasi silang antara regulasi diri dengan prokrastinasi akademik, dapat diketahui bahwa mahasiswa yang paling banyak memiliki tingkat prokrastinasi akademik yang sedang adalah juga memiliki tingkat regulasi diri yang tinggi, yaitu sebanyak 16 mahasiswa atau 53,3\% dan yang paling sedikit adalah mahasiwa memiliki tingkat prokrastinasi akademik yang rendah memiliki tingkat regulasi diri yang sangat tinggi, yaitu satu mahasiswa atau 3,3\%. Berdasarkan nilai chisquare tabulasi silang, dapat diketahui bahwa regulasi diri berasosiasi dengan prokrastinasi akademik, dengan nilai signifikansi 0,041 (p < $0,05)$.

Hasil penelitian ini menunjukkan bahwa regulasi diri memiliki hubungan dengan prokrastinasi akademik pada mahasiswa yang bekerja di Perguruan Tinggi Surabaya $(\mathrm{p}<0.05)$. Hasil penelitian ini menunjukkan adanya korelasi negatif antara regulasi diri dengan prokrastinasi akademik $(r=-0,611)$. Hasil tersebut sesuai dengan hasil penelitian sebelumnya yaitu penelitian Park dan Sperling (2012) menunjukkan bahwa prokrastinasi akademik berhubungan dengan pengaturan diri yang buruk. Mahasiswa yang melakukan prokrastinasi dengan tingkat yang tinggi sering menyebutkan bahwa mereka malas. Mereka tidak pandai mengikuti rencana dan niat awal. Mahasiswa ini menanggapi bahwa mereka biasanya merencanakan untuk mengerjakan di awal tetapi akhirnya melakukan di menit terakhir. Mereka tampak mudah terganggu oleh kegiatan menarik lainnya dan tidak bisa memotivasi diri mereka sendiri untuk bekerja seperti yang mereka rencanakan.

Pada penelitian ini, hasil uji tabulasi silang menunjukkan adanya asosiasi antara regulasi diri dengan prokrastinasi, dengan mahasiswa yang paling banyak memiliki tingkat prokrastinasi akademik yang sedang adalah juga memiliki tingkat regulasi diri yang tinggi, yaitu sebanyak 16 mahasiswa atau 53,3\%. Hasil penelitian ini menunjukkan bahwa meskipun mahasiswa yang bekerja memiliki regulasi diri yang tinggi, para mahasiswa tersebut masih melakukan prokrastinasi. Menurut pendapat peneliti hal tersebut menggambarkan bahwa walaupun mahasiswa tersebut memiliki kemampuan dalam mengatur diri yang baik, namun dari segi mengatur diri dalam menyelesaikan tugas akademik masih kurang. Dan juga Mahasiswa yang memiliki aktivitas rutin selain menjadi mahasiswa di perguruan tinggi yaitu bekerja, bertanggung jawab lebih berat dalam menyelesaikan tugas akademik serta tugas yang ada ditempatnya bekerja. Hal ini sesuai dengan penelitian Setyawati (2010) dan Utami (2011) menyebutkan bahwa peran yang dijalani yang lebih dari satu membuat munculnya konflik dalam menjalankan peran tersebut. Hasil penelitian Purwanto (2009) juga menemukan bahwa mahasiswa yang bekerja dan telah berkeluarga mengalami kesulitan dalam mengatur diri ketika belajar secara mandiri di luar perkuliahan tatap muka yang disebabkan oleh faktor internal seperti malas dan kurang gigih terlalu mengandalkan orang lain dan faktor 
eksternal yaitu tugas yang banyak di berbagai perannya. Hasil penelitian tersebut mendukung pendapat Steel (2007) yang menyatakan bahwa prokrastinasi merupakan tindakan sukarela yang berhubungan dengan regulasi diri sebagai bentuk sebuah kegagalan regulasi diri yang mendasar. Steel (2007) menghubungkan kegagalan pengaturan diri yang disengaja dengan prokrastinasi, yang merupakan cara individu secara sadar dan sengaja untuk gagal dan membiarkan dirinya sendiri tidak melakukan sesuatu.

Mahasiswa mengakui bahwa prokrastinasi adalah perilaku yang tidak baik dan menunjukkan niat untuk menguranginya karena mereka percaya bahwa mereka akan bekerja lebih baik tanpa prokrastinasi. Namun, mereka terus melakukan prokrastinasi. Mahasiswa yang melakukan prokrastinasi yang tinggi percaya bahwa mereka tidak dapat mengubah perilaku menunda-nunda mereka. Di sisi lain, mahasiswa yang tingkat prokrastinasinya rendah sudah menjadwalkan waktu bekerja diawal dengan mempertimbangkan kegiatan lain yang harus dilibatkan. Mereka percaya bahwa mereka punya cukup waktu untuk menyelesaikan tugas dan melaksanakannya sesuai dengan jadwal dan rencana yang dibuat. Mahasiswa yang tingkat prokrastinasinya rendah, secara umum, mencerminkan regulasi diri yang baik dari perilaku mereka dalam menghadapi gangguan dan komitmen yang tinggi untuk mencapai tujuan mereka. Pendapat tersebut sesuai dengan Miller dan Brown (1991) yang menyatakan bahwa individu akan melakukan prokrastinasi bila tidak memenuhi ketujuh dimensi regulasi diri, yaitu menerima informasi yang relevan, mengevaluasi informasi dan membandingkan ke norma, memicu perubahan, mencari opsi pilihan, merumuskan rencana, menerapkan rencana dan menilai keefektifan rencana. Perilaku menundanunda dapat terjadi karena kegagalan atau kekurangan pada salah satu dari tujuh dimensi tersebut. Mahasiswa yang melakukan prokrastinasi tidak bisa melakukan perubahan terhadap perilaku mereka dan mereka tidak bisa mengikuti dan menerapkan rencana awal dengan efektif. Sedangkan mahasiswa yang memiliki tingkat prokrastinasi yang rendah dapat berkomitmen sesuai rencana awal dan dapat melakukan perubahan dan mencari pilihan yang mendukung rencana awal mereka saat menghadapi gangguan.

Terdapat kesesuaian komponen-komponen dari teori prokrastinasi Milgram (1991) dengan aspek dari teori regulasi diri Zimmerman dan Schunk (dalam Ropp, 1999), pada mulanya tidak semua individu sengaja melakukan prokrastinasi, akan tetapi karena dia mempunyai banyak tugas dan tanggung jawab maka tidak semua tugas dapat terselesaikan dengan waktu yang tepat dan hasil yang maksimal, namun apabila individu tersebut melakukan penjadwalan tugas dengan kritis, mampu mengorganisasikan tugas primer maupun sekunder dan mampu merealisasikan hal-hal tersebut, maka kecil kemungkinannya individu itu melakukan prokrastinasi walaupun tidak disengaja. Dengan kata lain dia dapat menurunkan tingkat prokrastinasi dengan cara meningkatkan regulasi diri. Hal tersebut sesuai dengan hasil penelitian ini yang menunjukkan bahwa mayoritas mahasiswa yang bekerja tersebut mengalami prokrastinasi akademik yang tergolong sedang, memiliki regulasi diri yang tinggi. Sehingga terdapat kesimpulan bahwa semakin tinggi regulasi diri pada individu, maka semakin rendah prokrastinasi pada individu tersebut. Pada penelitian ini menjelaskan bahwa adanya hubungan regulasi diri dengan prokrastinasi akademik mengkhusus pada mahasiswa yang memiliki aktivitas rutin lain selain kuliah, yaitu mahasiswa yang kuliah sambil bekerja. Sehingga beban dan tanggung jawab yang dialami lebih banyak dibandingkan pada mahasiswa yang tidak bekerja, yang hanya memiliki aktivitas rutin dalam menyelesaikan tugas-tugas akademik saja. Sehingga pada subjek hasil penelitian yang dipaparkan kemampuan mengatur diri mereka melakukan tanggung jawab mengerjakan tugas akademik serta tugas dalam pekerjaannya.

\section{Simpulan dan Saran}

Penelitian ini bertujuan untuk mengetahui apakah ada hubungan antara prokrastinasi akademik dengan regulasi diri yang dialami oleh mahasiswa Magister yang bekerja pada Perguruan Tinggi di Surabaya. Berdasarkan hasil analisis yang telah dilakukan oleh peneliti dapat disimpulkan bahwa terdapat hubungan antara regulasi diri dengan prokrastinasi akademik pada mahasiswa Magister yang bekerja pada Perguruan Tinggi di Surabaya. Arah hubungan antara regulasi diri dengan prokrastinasi akademik pada mahasiswa Magister yang bekerja pada Perguruan Tinggi di Surabaya adalah negatif atau terbalik, yang berarti semakin tinggi regulasi diri mahasiswa, maka akan semakin rendah tingkat prokrastinasi akademiknya dan sebaliknya, semakin tinggi prokrastinasi 
akademik mahasiswa akan semakin rendah tingkat regulasi dirinya.

Saran yang peneliti dapat berikan untuk penelitian selanjutnya adalah menambahkan variabel mediator dan atau variabel independen lain untuk meneliti prokrastinasi secara lebih mendalam. Selain itu juga penelitian selanjutnya diharapkan meneliti pengaruh antara regulasi diri dengan prokrastinasi. Penelitian selanjutnya juga dapat melengkapi metode penelitian dengan menambahkan jumlah subjek yang lebih banyak agar penelitian lebih beragam dan menambahkan metode penelitian, mungkin dengan menggunakan wawancara untuk mengetahui alasan subjek melakukan prokrastinasi. Saran untuk mahasiwa magister yang bekerja adalah mahasiswa dapat lebih meningkatkan tingkat regulasi dirinya, karena diharapkan dengan meningkatnya tingkat regulasi diri, tingkat prokrastinasi akademik yang dilakukan akan berkurang. Hal ini dapat meminimalisir dampak negatif yang timbul karena prokrastinasi akademik.

Saran peniliti untuk meningkatkan regulasi diri menurut Steel (2007) menganjurkan untuk mengatur isyarat yang mengganggu dapat memfasilitasi pencegahan prokrastinasi. Misalnya, jika seseorang terganggu oleh halaman browser Web yang terbuka yang akan memudahkan untuk memulai obrolan melalui media sosial, maka dengan menutup browser Web saat mengerjakan tugas bisa kurangi prokrastinasi. Cara lainnya adalah membuat tenggat waktu yang ketat. Semakin banyak pilihan yang dimiliki mahasiswa, semakin besar kemungkinan mereka akan terbagi perhatiannya dan menunda-nunda. Mengurangi jumlah poin pilihan dapat membantu membangun kebiasaan produktif dan mengurangi kecenderungan untuk menunda-nunda. Menciptakan jadwal yang ketat untuk tenggat waktu penugasan dengan pos pemeriksaan waktu yang membantu mahasiswa menunda penyelesaian tugas.

\section{Ucapan Terimakasih}

Terima kasih kepada semua pihak yang telah membantu penyelesaian jurnal penelitian ini, terima kasih kerjasamanya sehingga penelitian ini bisa selesai dengan baik.

\section{DAFTAR PUSTAKA}

Motivasi Menghafal Al Quran Dengan Prokrastinasi Menghafal Al Quran Pada Mahasantri Nurus Shofa Malang. (Skripsi). Fakultas Psikologi Universitas Islam Negeri Maulana Malik Ibrahim Malang", 2019.

[2] A. Saifuddin, "Tes Prestasi: Fungsi dan Pengembangan Pengukuran Prestasi Belajar". Yogyakarta: Pustaka Pelajar, 1996.

[3] A. Saifuddin, " Metode Penelitian". Yogyakarta: Pustaka Pelajar.

[4] C. V. Bertan, C. V., A. K. Dundu, and R. J. M. Mandagi, "Pengaruh Pendayagunaan Sumber Daya Manusia (Tenaga Kerja) terhadap Hasil Pekerjaan (Studi Kasus Perumahan Taman Mapanget Raya (Tamara)". Jurnal Sipil Statik, vol. 4 no.1 , 13-20, 2016.

[5] C. Neville, "Procrastination: What It Is. Why We Do It. What We Can Do About It.", Bradford: University of Bradford, School of Management, 2007.

[6] D. Ross, "Student Psyche Report". Retrieved from https://www.prnewswire.com/ newsreleases/eighty-seven-percent-of-highschool-and-college-students-are-selfproclaimed-procrastinators260750441.html, 2014.

[7] Ferrari, J. R., Johnson, and J. L. Mc Cown, Procrastination and Task Avoidance. New York : Plenum Press, 1995

[8] F. S. Putri, "Hubungan antara Regulasi Diri dengan Efikasi Diri Pengambilan Keputusan Karir pada Siswa SMK Negeri 5 Surabaya. (Skripsi)". Tidak Diterbitkan. Fakultas Psikologi Universitas Airlangga Surabaya, 2016.

[9] J. Ford, Procrastination and the College Student: An Analysis on Contributing Factors and Academic Consequences. Education Undergraduate Research,15. Retrieved from https://knowledge.e.southern.edu/underg

K. Green, "Psychosocial Factors Affecting Dissertation Completion". New Directions For Higher Education, vol. 1 no.99, pp.57- 
64, 1997.

[11] L. J. Solomon, and E. D. Rothblum, "Academic Procrastination : Frequency and Cognitive Behavioral Correlates" Journal of Counseling Psychology, vol. 31, no. 4, pp. 503-509, 1984.

[12] M. Mastuti, M. "Memahami Perilaku Prokrastinasi Akademik Berdasar Tingkat Self Regulation Learning", Jurnal Psikologi Indonesia, vol. 6, no.1, pp. 55-61, 2009.

[13] Muslimah, "Hubungan antara Regulasi Diri dengan Prokrastinasi dalam menghafal AlQur'an Mahasiswa UIN Maulana Malik Ibrahim Malang. (Skripsi)" Fakultas Psikologi UIN Maulana Malik Ibrahim Malang: Tidak diterbitkan, 2016.

[14] P. Steel, "The nature of procrastination: A meta-analytic and theoretical review of quintessential self-regulatory failure," Psychological Bulletin, vol. 133, no. 1, pp. 65-94, 2007.

[15] Q. G., Jiao, D. Voseles, K. M. T., Collins, and A. J. Onwuegbuzie "Academic Procrastination and The Performance of Gradute-Level Cooperative". Journal of the Scholarship of Teaching and Learning, vol. 11 no.1, pp. 119-138, 2011.

[16] R., Klassen, L., Krawchuk, and S. Rajani, "Academic procrastination of undergraduates: Low self-efficacy to selfregulate predicts higher levels of procrastination" Contemporary Educational Psychology, vol. 33 no. 4, pp. 915-931, 2008

[17] R. Azis, "Model Perilaku Prokrastinasi Akademik Mahasiswa Pascasarjana". Journal of Islamic Education, vol.1 no. 2. pp. 269-295, 2015.

[18] S. Park, and R. Sperling, "Academic Procrastinators and Their Self-Regulation. Psychology", vol. 03, no.1. pp. 12-23, 2012.

[19] T. A. Pychyl, and G. I. Flett," Procrastination and Self-Regulatory Failure: An Introduction to the Special Issue", Journal of Rational Emotion Cognitive Behavior, vol. 1, no. 30: pp. 203-212, 2012.

[20] The Association for Quantitative Survey, "Survey". Retrieved May 31, 2017 from https://www.aqr.org.uk/glossary/survey,
2016.

[21] W. R. Miller, and J. M. Brown, "Selfregulation as a conceptual basis for the prevention and treatment of addictive behaviours. In N. Heather, W. R. Miller \& J. Greeley (Eds.), Self-control and the addictive behaviours (pp. 3-79). Sydney: Maxwell Macmillan Publishing Australia, 1991. 